\title{
Wine Production and Exchange and the Value of Wine Consumption in Sixth-century BC Etruria
}

Corinna Riva, Institute of Archaeology, University College London, 31-34 Gordon Square, London, WC1H OPY, UK

e-mail: c.riva@ucl.ac.uk

\begin{abstract}
This paper attempts to bridge the gulf between two often separate research agendas in Archaic period Etruria, one concerned with the archaeology of wine and agricultural production and redistribution, the other with figured representations of drinking and the associated symbolic visual language. It does so by examining the relationship between changing processes of production, consumption and exchange and the symbolism of drinking in the visual and material culture of sixth-century BC Tyrrhenian Etruria. In this analysis, I maintain that changing modes of agricultural production and distribution had an impact on such symbolism in elite funerary and domestic contexts, with key evidence also coming from sanctuaries. In particular, it is argued that during the seventh century $B C$, the visual language related to wine drinking alludes to experiences of bodily otherness; this is indicated by the symbolic correlation between accessibility to wine, the dangers of maritime travel and death. From the sixth century $B C$, we can trace a shift towards a visual language that centred on cultural difference or otherness: this is noticeable in the introduction of Dionysiac imagery and new mythological narratives of cross-cultural encounters, as well as a new emphasis on codified drinking and culturally differentiated drinking vessels. This shift is more or less contemporary with other changes, namely the production and distribution of
\end{abstract}


agricultural surplus in the Tyrrhenian region and beyond, and shifting values of objects in that exchange.

Keywords: agricultural surplus, central Mediterranean, distribution and gift exchange, south Etruria, value, visual symbolism, wine production and consumption

\section{Introduction}

Scholarship on wine production, consumption and exchange in sixth-century BC Etruria has followed two agendas, one concerned with production and redistribution — with limited success due to scarce pre-fifth-century evidence - and the other with the symbolism of wine drinking in ceramic and tomb-wall painting (e.g. d'Agostino and Cerchiai 1999; Cerchiai 2002; Bonaudo 2006-2007). Recent research has tried to bring these two subjects together (Ciacci et al. 2012), but attempts have been more successful for other locations, notably southern France (Dietler 2005) and Spain, where evidence for wine production at Iberian sites, Alt de Benimaquìa (Alicante_-Gómez Bellard and Guerin1995) and La Quéjola (Albacete_-Blánquez 1996), can be combined with other research on drinking practices (Celestino Pérez 2001).

The present study similarly attempts to combine both agendas, by examining the relationship between production, consumption and exchange and the symbolism of drinking in sixth-century Tyrrhenian south Etruria. Changing modes of agricultural production and distribution, I argue, had an impact on such symbolism in elite funerary and domestic contexts, and in sanctuaries. The seventh-century BC visual language of drinking alludes in particular to experiences of bodily otherness, as seen in the symbolic correlation between access to wine and the dangers of maritime travel and death. From the sixth century, the introduction of Dionysiac imagery, of myths about cross-cultural encounters, and a new emphasis on codified drinking indicate a shift towards cultural otherness or difference; and 
all this occurs with what I call a depersonification in wine consumption and gift exchange (Riva 2010a). This shift is contemporary with changing agricultural production and exchange, and shifting values of objects.

By exploring these developments, I aim to contribute to our understanding of the broader picture of sixth-century Etruria, where, scholars argue, a city-state commercial economy replaced a prestige gift-exchange economy (Perkins 2012: 422-23). The ways in which this shift took place, however, remain unclear, and I propose to focus on changing social relations rather than impose inaccurate dichotomies between gift and commodity, prestige-driven and commercial economies (Bourdieu 1977: 171-72; Appadurai 1986: 11 $13)$.

\section{The Values of Objects, the Value of Social Relations}

Interrregional exchange grew in the Tyrrhenian Sea region (Figure 1) from the end of the seventh into the sixth century BC and incorporated regions farther west. This is shown by increasing coastal trade with Phoenician settlements in southern Sardinia - the secondgreatest import area of Archaic (630-480 BC) Etruscan pottery after the French coast (Santocchini Gerg 2014: 2) — and by the establishment of Greek Massalia at the mouth of the Rhone around $600 \mathrm{BC}$ and indigenous sites in southern France (Dietler 2005; Gailledrat 2015).

\section{$>$ Insert Figure 1 about here $<<$}

The growth of Etruscan coastal trading posts or emporia corresponds to surging maritime links: Gravisca, near Tarquinia, for example, was established ca. 590 BC, concurrent with the beginning of greater production of amphorae in Etruria and their earliest exports. In the sixth century BC, more Etruscan amphorae reached southern France; here, the combination of amphorae with bucchero kantharoi, Etruscan drinking vessels also exported 
to Sardinia (Santocchini Gerg 2014, 248-52), has led to suggestions that Etruscan trade included wine (Gras 1986: 355; Long and Surrisseau 2002) — as is now confirmed by biomolecular analysis of pre-475 BC amphorae from Lattes in eastern Languedoc (McGovern et al. 2013). After roughly $540 \mathrm{BC}$ and through to the late sixth century, exports to southern France decreased as Ionian and Attic ceramic drinking vessels increased, although the occurrence of Etruscan amphorae is variable there even before considering the unparalleled record at Lattes (Lebeaupin et al. 2008). In Sardinia, we see a complementary, albeit distinct, trajectory: in the third quarter of the sixth century BC, Ionian B2 cups, widely distributed from Etruria to Spain and probably produced in southern Italy or Sicily (Krotscheck 2015), replaced Etrusco-Corinthian pottery (Santocchini Gerg 2014: 212-13). In south Etruria, the middle of the sixth century BC also saw an upsurge of Attic Greek pottery.

Against this background, scholars have detected social change in various kinds of evidence, from epigraphic and ceramic remains, to growing urban and rural settlements (Rendeli 1993; Cifani 2002), and domestic (e.g. Camporeale 1997; Bellelli 2012) and funerary contexts (Izzet 2007: 87-121) showing a more complex social hierarchy than previously. Inscriptions are particularly helpful: seventh-century BC and near-contemporary objects bear inscriptions that contain the concept of gift (mulu), indicating gift giving or, alternatively, objects' ownership. In either case, the inscription made the object 'speak', infusing it with personhood: muluvanice, translated as 'me donated by ...' (Maras 2009: 5456), merged the gift with the biographies of the exchange partners (Riva 2010a). The objects bearing these earlier inscriptions, often wine-drinking vessels like bucchero kantharoi, and their provenance from elite tombs and houses suggest aristocratic gift giving (Wallace 2008: 454). This personal gift exchange is progressively replaced, in the sixth century BC, by gift exchange of similar objects offered to the deity at urban and emporia sanctuaries: on these votives, the inscriptions 'speak' of the gift-recipient only, the deity, putting emphasis on the 
latter as gift-owner and the completion of the exchange (Carraro 2007: 70). Different giftgiving verbs also indicate this shift: $m u l$ - and tur- are the verbal forms used, respectively, in inscriptions of personal and sometimes votive gifts, and in those of later votive offerings from the last quarter of the sixth century BC (Maras 2009: 29-31, 33-34, 53, 57, 67). Furthermore, non-elite single names of worshippers inscribed on ex-votos show a socially wider participation in religion (Maras 2009: 210-11; 2013: 200).

Concurrently, the association of drinking, pouring and oil-containing vessels with non-elite contexts indicates broader access to practices such as drinking and the use of oil (Szilagyi 1998: 415-17; Avramidou 2006: 575). Scholars have linked these social changes to the growing production of Etrusco-Corinthian pottery, first made at Vulci in the last thirty years of the seventh century BC (Szilagyi 1998). This production has been recorded at Caere and Tarquinia in the first 25 years after the turn of the century, and it stands out for the quadrupled output at Vulci in the two decades before the middle of the sixth century BC. Scholars have matched this growth with ceramic standardised shapes and decoration of supposedly inferior artistic quality, seemingly indicating a 'mass production' for non-elites (Szilagyi 1998: 414; Gabrielli 2010: 495-96) and thus changing values of these vessels (Gabrielli 2010: 515). Such a characterisation, however, remains contentious because of a superficial and unverified claim of standardised production.

Emphasising objects' fluctuating values to detect social change, however, is pertinent, and has great interpretive potential as long as one understands these fluctuations as a result and in light of changing social relations. This is because material production is about social production: through the production of goods social relations are created, maintained and transformed (Graeber 2001). These relations are, in turn, articulated through and given meaning by worldviews and cosmologies of social groups: Graeber (2001: 71-88) calls this moral or 'social' value, to highlight the symbolic systems of meaning based on what those 
groups socially and morally valued. The values of objects are not simply created in exchange, but are also shaped by that 'social value' communicated in public arenas through ritualised actions; we cannot therefore understand objects' values unless we consider them in relation to the 'social value' that gives meaning to social relations (Graeber 2013; Lambek 2013). Previous studies have examined value creation in sixth-century BC Mediterranean exchange, notably in southern France (Dietler 2005) and across the Mediterranean (Foxhall 1998), but they have focused on consumption only. More recently, scholars have demonstrated the heuristic potential of examining the construction of value (Papadopoulos and Urton 2012).

Approaching value in relation to social and material production allows me to explore how changes in modes of production and exchange correspond to shifting values of drinking equipment and hence social relations in Etruria. Thus, bucchero kantharoi gained a transactional value when exported outside Etruria (Riva 2010a). Their much-reduced presence in elite drinking services was soon followed by the end of their export, although-I argue below - this matched their use in Etruscan ritualised contexts. This entanglement in regimes of value (Appadurai 1986: 4) is simultaneous with changes in the symbolic system informing the elite visual and material culture of drinking that was centred on the person, the body and bodily otherness: evidence of this is also seen in the 'speaking' inscriptions that merge the person's and vessel's biography, thus indicating personification in wine consumption (Riva 2010a). This gave way, in the sixth century BC, to a process through which gifts were depersonified as reciprocity relations changed: the elite person-gift was superseded by the deity-gift at the sanctuary. Here, drinking vessels notably dominate inscribed votives used for libation (Maras 2009: 162-72). Thus, in the late eighth and seventh centuries $\mathrm{BC}$, wine was procured through personal reciprocity relations across cultural boundaries, but within social confines: this is attested by the restricted circulation of mythological stories on drinking vessels (Osborne 2007: 89) and the deposition of inscribed 
person-gifts, drinking sets and non-Etruscan amphorae in high-status burials (Rizzo 1990). From the end of the seventh century BC, I will argue, the elites' control of surplus production and redistribution outside Etruria broadened accessibility to wine and other produce, affecting social relations in production and exchange. I begin by discussing this production before tackling seventh-century BC symbolism.

\section{Wine Production and Agricultural Surplus}

The beginning of ritual drinking and libation from the last decades of the ninth century BC (Delpino 2007: 137-41; Bartoloni 2007: 148; Botto 2010: 153-55) suggests an increasing use of alcohol, including wine that may have been imported from the eastern Mediterranean (on local seventh-century BC production see Gran-Aymerich and Domínguez-Arranz 2011: 1065). Starting with a Levantine-type example from a late eighth-century BC grave at Vulci/Poggio Maremma (Botto 2008: 144), non-Etruscan amphorae are mostly found in funerary contexts (Rizzo 1990), which coincides with a greater visibility of high-status groups in the seventh century $\mathrm{BC}$ and the growing complexity of drinking rituals at the tomb (Bartoloni et al. 2012) and in domestic contexts such as Murlo (Berkin 2003: 119-27), La Castellina (Gran-Aymerich and Domínguez-Arranz 2011: 404-408, 1182-94) and Ficana in Latium (Rathje 1983).

By the early sixth century BC, as Etruscan emporia were established, the Etruscan amphora record at underwater and terrestrial sites between Etruria and the French Midi documents the beginning of the export of agricultural surplus, whether wine or other goods (Dietler 2005: 40-47). This situation matches the survey record in Etruria, which shows higher numbers of rural sites in the Tolfa Hills between Tarquinia and Caere, for example, and the Albegna Valley (Rendeli 1993: 329-48; Perkins 1999: 28-33, 168; Cerasuolo 2012: 143-50). In the latter area, the number of rural sites increases twofold in the sixth century BC 
(Perkins 1999: 34), concurrent with the growth of a settlement at Doganella, five km from Marsiliana, which is interpreted as an amphora production and distribution centre (Perkins and Walker 1990). Most of these sites are difficult to date precisely, and only three farms have been well dated and excavated: Podere Tartuchino (Attolini and Perkins 1992), Poggio Alto near Marsiliana in the Albegna Valley (Zifferero 2010; Zifferero et al. 2011) and Pian d'Alma near Vetulonia (Paribeni 2009). All three, established more or less contemporaneously in the late sixth century BC, show a pattern, once we consider them against Doganella and other coeval farms in Rome's hinterland, such as the Auditorium villa (Carandini et al. 2007: 72-102; Morandini 2011: 82). The pattern is one of more intense agricultural exploitation and local elite control of surplus production for export. Three sets of evidence indicate this: the architecture and archaeology of the farms, the funerary deposition of local amphorae, and the estimated scale of surplus produced.

First, apart from the $100 \mathrm{sq} \mathrm{m}$ Tartuchino farm, those at Pian d'Alma (200 sq m), Marsiliana (400 sq m) and Auditorium are large complexes: their rectangular plan with rooms distributed around a courtyard is also found in urban architecture and may be an evolution from earlier elite residences (Zifferero 2010: 17; Morandini 2011: 85). The farms contained living spaces and rooms for the processing and storage of agricultural produce. At Marsiliana, for instance, storage vessels included pithoi (large storage jars), an eastern-Greek amphora and Etruscan Py-3C-type amphorae whose fabric matches that of the amphorae from Doganella where they were probably produced (Zifferero 2017; Zifferero et al. 2011: 303308). At Pian d'Alma, a single multi-functional room (A) hosted textile making and wineand oil-producing facilities (Morandini 2011: 83). Significantly, although Rome's northern hinterland differs from south Etruria, of the coeval, similarly large or larger 67 farms identified through survey there, 38 continued to be occupied and became villas (Carandini et al. 2007: 95). In the Albegna Valley, the location of these rural residences often coincides 
with earlier tumulus burials and indicates continued elite occupation (Zifferero et al. 2011: 295-303).

Second, the deposition of Etruscan amphorae in tombs - mostly limited to Vulci, its hinterland and the area around Volsinii and Chiusi-from the last quarter of the seventh to the first half of the sixth century BC is significant (Nardi and Pandolfini 1985; Rizzo 1990: 2324). Elite seventh-century BC tombs also contained storage vessels such as red impasto pithoi at Caere and ollae. These pithoi, however, were heavily decorated and conceivably created for the grave (Serra Ridgway 2010), while ollae were containers of liquids at the banquet (Bartoloni et al. 2012: 228); both are unlike transport containers. Some scholars have noted the non-elite character of burials containing Etruscan amphorae vis-à-vis the richer gravegoods of earlier burials containing imported amphorae (Rizzo 1990: 27-28); others interpret the declining funerary display of wealth as a levelling out of wealth distribution (Perkins and Walker 1990: 61). These arguments, however, underplay the funerary symbolism of material culture and conceptualise material wealth in too restricted terms, namely by the intrinsic preciousness or the long-distance provenience of objects. The evidence outlined above suggests changing ways in which elites displayed their social power. In fact, these burials represent a shift from a display of technological innovation characterising seventh-century BC elite tombs (Riva 2010b: 59-71), to advertising agricultural surplus and movement by the deposition of local amphorae that came to an end around the time that farms were established, including the three discussed here. Significantly, amphorae began to be placed in tombs at exactly the same time as they appeared as exports in southern France (Dedet and Py 2006: 130). Eight amphorae, seven of them from Vulci and the other from Calatia (Campania), bear gift-giving 'speaking' inscriptions (Bagnasco Gianni 1996: 194, 196, 20914). Several chamber tombs with these amphorae, notably in the Osteria cemetery at Vulci (Rizzo 1990: 100-57), also held abundant fine ware, including some imports, but mostly 
Etrusco-Corinthian and bucchero ceramics. They included entire drinking and banqueting sets, which, I argue below, reflect the codification of drinking.

The third piece of evidence that shows elite control of surplus production is the scale of the latter. This however, is difficult to estimate, for several reasons: (1) the excavated farms are few; (2) two out of three are in the same valley; and (3) storage and transport containers have not received the attention they deserve. Our earliest systematic studies concern amphorae from southern France, which have contributed to current arguments in favour of export-driven production (Bats 2006: 82; Zifferero et al. 2011: 296; Perkins 2012: 415). We still lack a systematic analysis of transport and storage containers-including pithoi, which have received even less attention. Yet as the only study of pithoi demonstrates (Perkins 1999), they are vital for estimating scale: in the Albegna Valley, the manufacture of pithoi and amphorae coexisted. Moreover, amphorae contained agricultural produce other than wine (Perkins and Walker 1990: 44), and, like pithoi, could be reused, which complicates any calculation of wine production. Notable is the reuse of a pithos, inscribed with vinun, as a water container for metallurgical activities at Gravisca (Fiorini 2005: 168). Residue analysis on pithoi and amphorae at Marsiliana has recorded biomarkers for fish, oil, resin and beeswax/honey, perhaps used as additives to wine (Zifferero et al. 2011: 310-15). Palaeobotanical evidence at Pian d'Alma indicates that Cornelian cherries may have been used to produce alcohol (Paribeni 2009: 669), a salutary reminder that alcohol does not necessarily imply wine, especially for local consumption (Kistler and Mohr 2015; Lentjes and Saltini Semerari 2016: 9). Despite these problems, two points help us to estimate surplus production.

First, on current evidence, the amount of amphorae at single sites between Etruria and southern France is not high enough to suggest export-driven production, at least not prior to the late sixth century BC. The amphora publication record at Gravisca, Pyrgi and Regisvilla, 
however, is poor, and little material of this phase has been published for these emporia (Cristofani et al. 1985). At the port of Puntata di Fonteblanda, Py3-type amphorae dominate the foundation strata at ca. 570-560 BC; the site, however, was short-lived, lasting only until ca. 540 BC, although Py4-type amphora fragments indicate fifth-century occupation (Ciampoltrini 2016: 41). Moreover, architectural terracottas similar to those from Murlo suggest an unexplored elite residence coeval to the port's foundation (Ciampoltrini 2016: 4142), well-placed to control the movement of surplus. Doganella, by contrast, has our best published amphora record and it shows household production (Perkins and Walkers 1990: 61), as well as production of Py-3C-type amphorae that have been found all over the valley, and further afield in Languedoc (Zifferero 2017). Even supposing that all exported amphorae carried wine, and recognising the diverse rate of imports at different sites across southern France, their occurrence, calculated by percentages and absolute numbers of fragments against the total number of fragments at these sites, is unremarkable; the exception is Lattes, where that occurrence peaked around 500-475 BC (93.45\%), and dropped to just over 5\% after 450 BC (Dedet and Py 2006: 124, table 1). Lattes's record matches the nearcontemporary Grand Ribaud F shipwreck that contained 1200-1500 Py4-type amphorae associated with vine shoots and grape pips (Long et al. 2006: 459-60). This exceptional cargo, which has been estimated to have held $300 \mathrm{hl}$ of wine in amphorae types well attested near Lattes (Long et al. 2006: 459-87), bears no comparison to the cargoes of much smaller shipwrecks. That this considerably larger volume of Etruscan exports is coeval with the emergence of the large farms previously noted may not be coincidental. Yet the amphorae come from a single wreck and were probably produced at or near Caere; in other words, this may be a single consignment from a poorly understood amphora-producing district.

Second, unlike redistribution, pre-fifth-century BC evidence for wine processing is scarce, consisting of installations at Pian d'Alma and Tartuchino, together with undateable 
stone basins found through survey (Brun 2012: 72-73). Much wine-making equipment was mobile, multi-functional and made of perishable material (Attolini and Perkins 1992: 122). Intensive and export-driven wine production would have left more traces, as is shown by the early sixth-century BC evidence of specialised wine-making at Alt de Benimaquìa in Spain (Gómez Bellard and Guerin 1995). Moreover, the annual production of 1575-1890 1 at Tartuchino, estimated on the basis of five to six fermentations per season (Attolini and Perkins 1992: 128), pales against the more than 12,000 1 that has been estimated to have been produced with ten wine presses using two basins at the fourth- to third-century BC Punic farm at Truncu 'e Molas (Oristano, Sardinia) (van Dommelen et al. 2012: 509).

All the above evidence points to household-run management of production, out of which an agricultural surplus, including wine, was created and, in some cases, exported, leading to the beginning of cash-crops in the late sixth century BC. Settlements like Doganella were key to surplus distribution; agricultural storage, however, characterised different farms and social groups across the Albegna Valley (Perkins 1999: 180-81; 2012: 419), suggesting that increased production was not motivated by long-distance export. The exported surplus, if not economically motivated, was likely moved by local elites who controlled larger surpluses and capitalised on their long-established and long-distance trade links. That the bucchero kantharos, an elite gift, accompanied amphorae to Languedoc is telling of those long-distance relationships. These changes in production and exchange affected relations among different social groups involved in them. Concurrently, the visual and material culture of elite drinking, the symbolism of which focused on bodily otherness in the seventh century BC, also changed. I now turn to consider this symbolism.

\section{Bodily Otherness in Seventh-century BC Symbolism}


Although drinking, an indigenous practice, was already a feature of Early Iron Age burial ritual, large-scale banqueting and drinking became a central means of elite social reproduction in the seventh century $\mathrm{BC}$ : the collective banquet was first institutionalised at funerals before it was displayed in other non-funerary contexts (Riva 2010b: 108-25). It was not just a matter of scale, however: these rituals involved new ways of drinking and food technologies, or technologies of the body (Riva 2010b: 146-50).

To the seventh century $\mathrm{BC}$ belong a series of painted images on banqueting/drinking vessels that depict maritime travel, exemplified by the naval skirmish on the well-known Aristonothos Krater, and now by an unparalleled depiction of two ships and their hulls on an impasto kantharos from a tomb near Veii (Arizza et al. 2013: 93-103, 107). Cerchiai (2002) has argued that these and other related images underlie a system of meaning in the visual culture of central Italian Tyrrhenian tombs that is linked to the imaginary of the sea. In the case of the Aristonothos Krater depicting Odysseus's blinding of Polyphemos on one side, for instance, Cerchiai associated the skirmish depicted on the other side with Odysseus's cunning skill, necessary for facing the mortal dangers of the sea. Analysing ceramic and tomb paintings, Cerchiai posited a homology between wine drinking, the sea and its dangersdiving into, travelling onto - and death, all of which provide experiences of otherness (d'Agostino and Cerchiai 1999: 61-71). These three spheres of alterity are related to bodily experience: intoxication, the underwater dimension of being in space and the ultimate otherness of death. Some of these images are depicted on early sixth-century BC EtruscoCorinthian vessels; significantly, Etruscan figurative representations of this period rarely display figurative, let alone narrative, decoration, but when they do, the decoration is almost always focused on the sea (Cristofani 1987b: 54-55; Gabrielli 2010: 374-75).

\section{$>$ Insert Figure 2 about here $<<$}


A key figure expressing the dangers of sea travel and death is the siren depicted on Corinthian, Etrusco-Corinthian and later Etruscan Black-Figure pottery. D’Agostino (1995) traced a link between Odysseus, who in Etruscan iconography is often linked to the siren, and Herakles. This is exemplified by two ivory pyxis vessels from a tomb at Chiusi, dated between the late seventh and early sixth century BC. Of the two, the so-called second Pania pyxis, displays one of Herakles's labours — the stealing of Geryon's cattle — on the middle frieze and, below, the escape of Odysseus and his companions from Polyphemos's cave. The better-known Pania pyxis (Figure 2) depicts the same escape scene with the figures moving towards a ship sailing with two amphorae and a helmsman on board towards a three-headed monster, interpreted as Skylla (Cristofani 1971; Menichetti 1994: 85) or Herakles's hydra (d'Agostino 1995: 206). D'Agostino noticed a simultaneity between the introduction of images related to Herakles's labours and episodes from the Odyssey in this and other Etruscan representations; he interpreted this by suggesting a complementarity of the two heroes on the basis of their similar iconography. This iconography may presuppose awareness of the character of the heroes, the only ones to have known the underworld and to have returned from it. Regarding the iconography of the siren, a notable representation on an Etrusco-Corinthian vessel comes from the so-called Gobbi Krater from Caere: here, a siren is behind Herakles, who moves towards Geryon's cattle and displays a fish tail, rather than the usual bird tail (Martelli 1987b: 289-91) (Figure 3a-b-c). This is one of the few and earliest example of a fish-tailed siren, symbolically conflating the sea and death.

\section{>>Insert Figures 3-4 about here $<<$}

The correlation between drinking, the siren and death lies in the siren's ability to provoke paralysis and forgetfulness in those listening to its fatal and addictive song, as described in Homer; this physical and psychological state is also induced by wine drinking, as emphasised in Greek lyric poetry (Pavlou 2012: 406-408). This correlation is also 
highlighted on an earlier White-on-Red amphora from Tomb 17/Banditaccia in Caere (ca. $630 \mathrm{BC}$ ), that depicts a ship moving towards a siren, preceded by a fish, a winged horse and a lion (Martelli 1987a) (Figure 4). Shown frontally with wings and human arms, this siren is similar to north-Syrian siren attachments on bronze cauldrons (Martelli 1987a: 7) that are found in seventh-century BC elite tombs; the painter's borrowing of the frontal siren from cauldrons was perhaps motivated by the role of these cauldrons in drinking rituals.

Matching the introduction of new technologies of the body at elite funerals (Riva 2010b: 146-50), bodily otherness thus stands at the basis of this system of meaning that underlies a specific cosmology. This cosmology, in turn, reflected the elites' social value (sensu Graeber), and the values of 'speaking' vessels circulating as person-gifts through reciprocity relations. Funerary rituals of commensality helped to highlight these relations and articulate this cosmology visually and materially for the elites' social reproduction. Accessibility to wine was crucial to these relations and therefore to the worldview underlying the system of meaning itself. This is indicated by the funerary deposition of imported amphorae and of Etruscan amphorae transformed into person-gifts through inscriptions.

Two other pieces of evidence are suggestive: first, the image of two ships and their hulls carrying horses and wine on the aforementioned impasto kantharos (Arizza et al. 2013: 101) highlights wine procurement. Deposited with other drinking vessels, this kantharos was associated with a banqueting service, a spear and a viticulture pruning hook (Arizza et al. 2013: 81, 111). Secondly, notable emphasis is placed on the gifted amphorae in the depiction of Odysseus's escape on the first Pania pyxis, and of the blinding of Polyphemos on a Caeretan White-on-Red pithos (ca. 640-630 BC) (Micozzi 2005) (Figure 5). On the pyxis, the depiction of the ship with two amphorae may refer to Odysseus's ship and to the wine given to Odysseus by Maron as a hospitality gift before his encounter with the cyclops (Odyssey 9.195-211): this would be an addition in the representation of the cyclops's encounter that is 
absent in Greek iconography (Govers Hopman 2012: 36). An emphasis on Maron's wine may be similarly be read in the choice by the painter of the pithos to place a western Phoenicianlooking amphora at the centre of the scene (Micozzi 2005: 261).

\section{$>$ Insert Figure 5 about here $<<$}

My suggestions complement the view according to which representations in Etruria of Polyphemos's blinding had little to do with the episode itself, but rather with a cultural model instructing the viewer-drinker what not to do in cross-cultural encounters such as drinking excessively, as the cyclops did, and which allowed Odysseus to escape (Bagnasco Gianni 2007: 9-12). The material culture of funerary drinking and libation corroborates this: while the use of local drinking vessels derived from an indigenous codified practice established in the Iron Age (Bartoloni et al. 2012: 206), the introduction of new vessels and food/drink technologies resulted in an undifferentiated and non-codified use of such vessels (Bartoloni et al. 2012: 257, 260). In some seventh-century BC elite tombs, moreover, preparing wine for drinking is emphasized by specialized equipment such as Cypro-Phoenician basins and bronze graters (Ridgway 1997; Belelli and Botto 2002: 290-93): such contexts highlight drinking as a habitus to be learnt rather than one already known. In the sixth century BC, the funerary deposition of this equipment declines, and the habitus of drinking and banqueting is displayed in a monumentalised form for the first time in non-funerary spaces, as at the residential complexes at Murlo and Acquarossa through terracotta friezes.

\section{Cultural Otherness in Sixth-century Symbolism}

While images of reclined banquets on these friezes are interpreted as the Hellenisation of Etruscan banquets, I propose we read changing drinking practices as a new phase of codification of these practices, one that coincides with increasing surplus production and movement, and the elite-controlled export of some of that surplus. These changes in 
production and exchange broadened the elites' trading networks, which in turn affected local and long-distance social relations. The emporia sanctuaries facilitated those networks, but also intensified cultural contact, accentuating cultural difference in religious worship. Significantly, mulu or muluvanice inscriptions never occur on imported votives at these sanctuaries (Maras 2009: 48). The total disappearance of the $m u l$ - verb form and the diffusion of the new tur- verb form on votive inscriptions in the fifth century BC indicates a radical transformation: the seventh-century BC concept of the gift (mulu) vanished and was substituted with the concept of the votives' ownership by the divinity (Maras 2009: 53-54, 67). Inscribing votives to indicate the deity's ownership, first seen at these sanctuaries, may have derived from a Greek practice (Maras 2009: 31). However, this evidence suggests that changing social relations as discussed above and the concomitant depersonification in gift exchange promoted the adoption of new dedicatory customs.

The export of bucchero kantharoi further emphasised cultural difference: as objects of exchange they became what Gras (1984: 329) called a 'valeur-sign' for Etruscan exports, and acquired a transactional value. At the same time, they maintained, if not reinforced, their ritual value in drinking ceremonies because of their transactional value (Thomas 1991: 199, 200). Kantharoi thus represent the potential slippage between gift and commodity that objects are subjected to in social performances, whether involving economic transactions or ceremonial events. Hence, there is an ambiguity in the status of the object itself, which social actors intervene to erase in order to perform their objectives successfully (Keane 1994; Miyazaki 2010: 251-54). The religious cross-cultural interaction at emporia amplified the conditions for such a slippage to occur. This very slippage, I suggest, promoted—among Etruscan elites - a codified mode of drinking, which helped define cultural difference at a time when the sociality of drinking and libation also occurred at the emporion sanctuaries. Cultural difference became central to these elites because it gave meaning to new reciprocity 
relations established along trading networks, and hence became the basis of the elites' changing worldview, which, in turn, affected their social value (sensu Graeber). This change can be inferred from three pieces of related evidence: first, the archaeological, visual and linguistic evidence of formalised uses of bucchero kantharoi; second, the introduction and appropriation of Dionysos and his attribute, the kantharos, in the elites' visual culture of drinking; and, third, the circulation of mythological narratives emphasising culturally specific rules of commensality.

\section{Kantharoi, Dionysos and Drinking Rules}

The differentiation, if not opposition, between the Greek drinking cup, the kylix and the highhandled kantharos has been noted before in the composition of drinking and banqueting services in burials and in the figurative evidence of funerary and non-funerary banquets: this differentiation was probably dictated by the different social roles of participants at the drinking ritual (Batino 1998: 28-29, 34). It ultimately signalled a codified use of culturallyspecific vessels, further confirmed by the semantic differentiation between high-handled cups like kantharoi and kyathoi, designated by the Etruscan word zavena, and low-handled shapes like kylikes (Bellelli and Benelli 2010: 19). Although no longer found in drinking sets of wealthy funerary contexts as frequently as before (Belelli Marchesini 2004: 110-12; Locatelli 2004: 84-85; Marchetti 2004: 24-26), the ritual value of kantharoi is also suggested by their use as votives. This is seen, for example, in the urban sanctuaries at Tarquinia (Locatelli 2001: 238-40; Duranti 2012), and in their role as centrepieces in non-funerary images of drinking ceremonies. They are, for instance, held by or handed to seated figures in ceremonies represented on cylinder-stamped decoration of Chiusine-type bucchero vessels, some of which come from an elite residence on Monte S. Paolo near Chiusi (Cappuccini 2011). Kantharoi also appear on two terracotta plaques from Tarquinia that probably 
decorated elite houses. On one, the vessel is held by a symposiast; on the other, it is placed on a table below the bed on which a banqueter sits, holding a knife (Romanelli 1948: 234, nos. 9, 42, fig. 25 a, b). As an unusual item in drinking scenes of this phase, the knife alludes to sacrifice, but the association of the kantharos with sacrifice is not isolated and reinforces the central role of the vessel in ritualised contexts. It is found on the Gobbi Krater, if two scenes on the friezes decorating the vessel's body and shoulder can be interpreted as sacrificial scenes (Martelli 1987b: 290). This association also occurs on the Black-Figure decoration of the so-called Ricci hydria from Caere (ca. 540 BC), where a complete sequence of sacrifice, from the preparation of animal carcasses to meat cooking, is overseen by Dionysos holding a kantharos (d'Agostino and Cerchiai 1999: 129-43).

That the kantharos was not an everyday drinking vessel can further be deduced from the manufacturing process: its high handles required skilled craftsmanship, particularly when of large size and made in very fine wares. The limited production of kantharoi in these wares confirms this: once fine bucchero sottile kantharoi slowly went out of production, kantharoi appeared in Attic Black-Figure pottery in limited numbers (Torelli 2004: 216-20). They are rare even in the Athenian Nikosthenic production aimed at Etruscan clients. Similarly, the number of Etruscan Black-Figure kantharoi is small (Paleothodoros 2011: 50).

The contemporaneous introduction and appropriation of a non-Etruscan god, Dionysos, and his attribute, the kantharos, in the elites' visual culture of drinking further underscore cultural difference at the base of elites' social value and must be understood against the uses of kantharoi just discussed. This appropriation began when the export of Etruscan amphorae, at least in the central Mediterranean's northern littorals, peaked; this is also the last phase of export of the bucchero kantharos type found outside Etruria (type $3 \mathrm{e}$ in Rasmussen 1979). Hence a kantharos-holding Dionysos entered the world of Etruscan drinking culture when his attribute, by which he was recognisable as the Greek god of wine, 
had become a culturally specific Etruscan hallmark of new reciprocity relations. As representations of a kantharos-holding Dionysos appeared for the first time in Attic Black Figure pottery ca. 560-550 BC (Moore 2010: 33), scholars have studied these representations with Athenian viewers in mind. They have underlined the transition between the image of Dionysos holding a rhyton and that of the god holding the kantharos as an iconographic shift indicating the passage between a wild world associated with the rhyton and drinking undiluted wine - that is, immoderately — and civilisation as symbolised by the kantharos (Lissarague 1987: 111, 86-88; Isler-Kerenyi 2007: 63, 156). However, these representations belong to some of the earliest Attic imports in Etruria and thus must be understood vis-à-vis Etruscan viewers, for whom the significance of kantharos-holding Dionysos derived, partly at least, from the use of the kantharos as a distinctly Etruscan vessel. This is likely to account for the interest in the new iconography of Dionysos in Etruria as soon as crafstmen used it in Athens, showing localised responses to broader iconographic innovations.

\section{$>>$ Insert Figure 6 about here $<<$}

Some of these early representations decorated so-called 'Tyrrhenian' amphorae, produced in Athens for an Etruscan market (Kluiver 1993; 2003: 19-23, 118-22). The other imported vessels bearing these representations are the renowned François Vase and a dinos or wine bowl (ca. 565-560 BC; Iozzo 2009) (Figure 6), both from Chiusi and depicting Dionysos at the wedding procession of Peleus and Thetis. This is the myth in which we have the earliest depictions of the god as seen on two other coeval Attic dinoi signed by Sophilos (Carpenter 1986: 1-12). On the Chiusi dinos, the god appears wearing a precious himation (outer garment), clenching an ivy branch with the right hand and raising the kantharos on the other. A recent drawing of this image (Iozzo 2009: 68, fig. 11) shows the hairlocks on the left-hand side of the god on his himation, as if he was facing the viewer rather than looking sideways like other participants in the procession. This would be one of two images of 
Dionysos facing the viewer; the other is in the François Vase's depiction of the same procession.

\section{> Insert Figure 7 about here $<<$}

On the François Vase (Figure 7), however, the kantharos is with Peleus; Dionysos is carrying a footed amphora, possibly an SOS amphora (Johnston 1987: 137, n. 17), used in Greece as a funerary vessel (Isler-Kerenyi 2007: 79), or an ovoid 'Tyrrhenian'-looking neckamphora (Kluiver 1993: 79, n. 219; 2003: 106, note 20). Scholars have long debated the meaning of this vessel: some have interpreted it as the golden amphora given to Thetis as a wedding present, which was later used as the urn of her son Achilles' ashes. Dionysos' central position on the krater, between the funeral games for Patroklos on the upper frieze and the pursuit of Troilus below, strengthens this possibility (Torelli 2007; Moore 2011). The iconography of the god at such an early date, however, had not been yet established, and craftsmen experimented (Carpenter 1986: 8-9).

\section{$>>$ Insert Figure 7 about here $<<$}

However we interpret Dionysos' amphora, it is nonetheless compelling that, from the extant evidence, only in two instances - two monumental wine-mixing vessels, both probably made on commission and possibly to suit Etruscan clients-Dionysos looks at the viewer: his frontal face may be a device to capture the viewer's attention (Carpenter 1986: 11-12; Moore 2010: 32). Importantly, this device served precisely at the point when a Greek god became incorporated into Etruscan culture and was eventually domesticated into a local god, as attested by fifth-century BC inscriptions of Etruscan Fufluns Pakies (Maras 2009: 35-36). Such a domestication, however, probably occurred earlier: the funerary characterisation of Dionysos is perceptible in Etruscan Black-Figure pottery as early as 550 BC (Werner 2005) and in Tarquinian tomb painting (Paleothodoros 2007; 2009: 51), signalling changing views on the afterlife. 
The third, final piece of evidence highlighting the significance of cultural difference in the elites' system of meaning is the introduction of a new iconography of cultural encounter, namely the peaceful convivial meeting of Herakles and the centaur Pholos, narrated in Stesichoros's Geryoneis (sixth century BC), and depicted on a series of Attic Black-Figure vessels, mostly amphorae (Brommer 1973: 178-82; Finglass and Davies 2014: 238-39, 290-93). The visual language of the meeting on these amphorae emphasises the knowledge of the rules of hospitality: Pholos offers Herakles mixed wine after opening his pithos. In the myth, other centaurs, attracted by the smell of wine, ran charging against Herakles, who accidentally caused Pholos's death. From the last third of the sixth century $\mathrm{BC}$, some of the Attic craftsmen painting these amphorae isolated the scene of the encounter from the centaurs' violence, and were the only ones to do so. Outside Attica, the theme was never depicted without the combat, except for the Gobbi Krater where Pholos is represented holding a kantharos - ubiquitous on amphora scenes where Pholos offers wine (Martelli 1987b: 290; d'Agostino and Cerchiai 1999: 160). Three scenes prevail on the amphorae: the encounter between Herakles and Pholos, the opening of the pithos, and the feasting. The representation of the feast follows the composition of contemporary Attic depictions of symposia — in fact the same composition adopted for depicting Herakles banqueting at Olympos (Verbanck-Piérard 1982: 147). On the earliest representation, on a belly amphora from Florence (Figure 8a-b), the feasting is mirrored on the vessel's other side where Dionysos appears reclined like Herakles and the Silens (elderly satyrs) pour wine like Pholos (Schauenburg 1971: 46-47, tafel 33). By offering Herakles diluted wine, Pholos enters the space of culture, knowing that drinking follows a culturally-specific code of practice (Valenza Mele 1986: 339-40).

\section{> Insert Figure 8 about here $<<$}


All the Attic Black-Figure vessels of known provenance that depict the encounter between Pholos and Herakles, leaving aside a series of lekythoi, are from Etruria (Brommer 1973: 178-82). One may reasonably assume from the current location of the unprovenanced vessels that they come from Etruria, too. All these images were thus probably intended for Etruscan viewers, to whom awareness of cultural difference and knowledge of culturallyspecific codes were key to the maintenance of new reciprocity relations. In highlighting that knowledge, these images provided a new iconography of cross-cultural encounters, in contrast to seventh-century violent encounters such as the blinding of Polyphemos. The vessels bearing these images may have thus been an Athenian production targeting Etruria. Reinforcing this suggestion is the fact that outside Attic Black-Figure iconography, the only image showing Pholos separated from the centaurs' combat is on the Gobbi Krater, where the painter isolated Pholos and the signifier of his act of sharing wine, the kantharos.

\section{Discussion and Conclusion}

The changes discussed thus far pertain to arenas where elites communicated their own worldviews and social value through ritual performance, whether drinking or libation, in tombs, banquet rooms and sanctuaries. These changes must be considered, first, in the broader contexts of social change and, secondly, in relation to the central Mediterranean more generally.

As elites' long-distance trading networks widened their reciprocity relations, social relations also changed locally and regionally: as discussed above, local surplus storage and movement occurred at different social levels across the Albegna Valley. Moreover, the production environment there stretched beyond the household: the addition of augite, a nonlocal mineral, to the clay of some pithoi indicates specialised craftsmanship, and the trade of either the pithoi themselves or the grit containing augite from its sources in northern Latium 
(Perkins 1999: 184-86). Elite-controlled surplus exports outside Etruria, in other words, occurred in tandem with local and regional surplus storage and distribution. Social relations also changed locally following the increasing production of recently introduced crops like the vine and olive. Unlike all other types of agriculture (wheat, legumes, oleoculture), viticulture required intensive labour all year round. A successful crop also depended on the viticulturist's expertise in evaluating a range of parameters such as temperature, moisture, altitude, soil condition and the timing of specific activities such as pruning (Hanson 1992; Isager and Skydsgaard 1995: 27-33). We can thus read some rural sites in a fresh light against this scenario of a production and labour cycle that knew no off-season.

In this multifarious environment of production and exchange, emporia sanctuaries were not just spaces of cross-cultural contact, but also a meeting point of different social groups, and not just elites, as attested by the epigraphic evidence (Maras 2009: 210-11; 2013). This evidence and the votives also show that the ceremonial dimension of early Archaic libations was identical to that of elite drinking (Maras 2009: 173): the transfer of gift giving from the tomb to the sanctuary involved an elite practice that remained so at the sanctuary. Elite religious worship therefore was not simply the mechanism for maintaining and affirming social relations, but also for expressing, in a broader social arena, a worldview that gave meaning to elites' relations and shaped their values. As knowledge of cultural otherness moulded this worldview, the elites deployed that knowledge as a form of social distinction vis-à-vis other groups. This is also documented by the adoption of new myths of crosscultural encounters, which pivoted around knowledge of the rules of hospitality.

That drinking and its symbolism constituted the means through which cultural difference was constructed and employed to different ends is a phenomenon not limited to Etruria. We see it in other central Mediterranean regions, at Greek and indigenous settlements in southern Italy. Noteworthy is the striking of coins, in the second half of the sixth century 
BC, by Naxos and Tyrrhenian Serdaioi, the latter an indigenous community(ies) near Laos (Brousseau 2010: 277-79), that show Dionysos on one side and a grape bunch on the other, next to their respective ethnic abbreviation. Both types of coinage have been linked to wine production and export (Van Der Mersch 1996: 167-68), although assessing the role of viticulture in agricultural production from earlier evidence in southern Italy has proven difficult (Lentjes and Saltini Semerari 2016). However, we have a different explanation for the appearance of this early Dionysiac coinage adopted, respectively, by a Sicilian Greek city-state and an indigenous frontier community with political links with Sybaris (Brousseau 2010). In both cases, the coinage was an 'active agent' (Papadopoulos 2012: 285) to construct a community's collective identity, and to reaffirm their respective cultural distinctiveness by highlighting the god of wine. Papadopoulos (2012) proposes this role for the early coinage of other southern Greek cities that struck symbols harking back to a heroic Achaian past. In the case of Naxos and Serdaioi, affirming their respective identities on coinage worked in quite different political contexts. Other frontier indigenous communities in Puglia and Basilicata constructed cultural distinction in other ways, through the elites' use of indigenous vessels for alcohol consumption (Colivicchi 2004).

All the above demonstrates that cultural difference expressed through drinking and/or the symbolism of wine served different cultural, social and political purposes across the central Mediterranean — from asserting a politico-cultural identity to locally affirming social standing, as in Etruria. Here, this difference came to encapsulate the elites' worldview, which gave meaning to changing social relations and was expressed in arenas where drinking practices were codified. This, I argue, co-existed with depersonification in reciprocity and exchange relations, reflecting profound social transformations. Changing relations, and hence the elites' social value, in turn affected the values of objects within and outside Etruria. Bucchero kantharoi are emblematic: their transactional value in elite-controlled exchange 
enhanced rather than diminished their ritual value. At Vulci, some kantharoi of the type that was exported, but of larger size, were deposited in tombs together with Etruscan amphorae (Rizzo 1990: 97, 129). The association of amphorae with larger kantharoi encapsulated, at once, the vessels' transactional value that strengthened their ritualisation at funerals, and supported a new form of social power that originated in the capitalisation of agricultural production. The role of these vessels in rituals also explains the incorporation and domestication of a kantharos-holding Dionysos in the elites' culture of drinking; it ultimately demonstrates the need to explain such phenomena, otherwise wrongly understood as Hellenisation, through a contextual analysis of different types of evidence.

Like kantharoi, wine also moved across boundaries between gift and commodity, just like other products such as oil. However, our archaeological and palaeobotanical evidence from pre-fifth century $\mathrm{BC}$ stratigraphic contexts for examining this is wanting. We still lack a systematic and thorough research investment in this type of evidence, a situation mirrored for southern Italy (Brun 2012: 103); most of that investment concerns the Albegna valley, which prevents us from assessing likely regional variations (Lentjes and Saltini Semerari 2016: 9). Thirty years ago, the late Mauro Cristofani (1987a: 40) called for more excavation of Etruscan farms; today, we only have three such sites, a meagre number when compared to the commitment towards monumental and funerary contexts. These sites may be the tip of the iceberg for a picture only glimpsed from the evidence available thus far. We can use this evidence, as I have tried to do here, to understand the relationship between production, consumption and social change, but we need more commitment to explore this relationship on the ground.

\section{Acknowledgments}


This paper arose from research carried out during my stay at the Getty Villa in 2013. I thank my fellow scholars of that year, and the Getty curators and staff for discussing many of the ideas that took shape there, in particular Gert Jan Wijngaarden, Nancy Um and Sandy Blakely. Mike Rowlands, Robin Osborne, John Papadopoulos, Dave Wengrow and Tom Carpenter read drafts at various stages and gave some key advice; Nicholas Purcell invited me to give a seminar and offered further advice. I also wish to thank Peter van Dommelen for fruitful discussions on agricultural production. Lastly, I thank the seminar audiences at the Getty, Cambridge, Oxford and the Institute of Classical Studies in London for further feedback and the Pottery Research Network members led by Mark Stansbury-O'Donnell and Liz Langridge-Noti for introducing me to and teaching me about the immense ocean of vasepainting scholarship.

\section{About the Author}

Corinna Riva studies and publishes on Iron Age Italy, with a special interest in Etruria and other central Italian regions, in the context of the central Mediterranean of the first millennium BC. She is the author of The Urbanisation of Etruria: Funerary Practices and Social Change 700-600 BC (Cambridge: Cambridge University Press, 2010). She has codirected the Upper Esino Valley Survey and, most recently, has begun a collaboration with the Soprintendenza Archeologia del Lazio e dell'Etruria Meridionale on the Etruscan ports of Vulci.

\section{Classical Authors and Texts}

Homer, Odyssey.

\section{References}


Appadurai, A.

1986 Introduction: commodities and the politics of value. In A. Appadurai (ed.), The Social Life of Things: Commodities in Cultural Perspective, 3-91. Cambridge: Cambridge University Press.

Arizza, M., A. De Cristofaro, A. Piergrossi and D. Rossi

2013 La tomba di un aristocratico naukleros dall'agro veientano. Il kantharos con scena di navigazione di via A. d'Avack. Archeologia Classica 64: 51-131.

Attolini, I., and P. Perkins

1992 The excavation of an Etruscan farm at Podere Tartuchino. Papers of the British School at Rome 60: 1-76.

Avramidou, A.

2006 Attic vases in Etruria: another view on the divine banquet cup by the Codrus Painter. American Journal of Archaeology 110: 565-79.

Bagnasco Gianni, G.

1996 Oggetti iscritti di epoca orientalizzante in Etruria. Florence: Leo S. Olschki.

2007 Aristonothos: il vaso. Aristonothos: Scritti per il Mediterraneo Antico 1: 5-15.

Bartoloni, G.

2007 La diffusione della vitivinicultura in Etruria: il quadro della cultura materiale a partire dell'età del ferro. In A. Ciacci, P. Rendini and A. Zifferero (eds.), Archeologia della vite e del vino in Etruria, 147-54. Siena: Ci.Vin.

Bartoloni G., V. Acconcia and S. ten Kortenaar

2012 Viticultura e consumo del vino in Etruria: la cultura materiale tra la fine dell'età del Ferro e l'Orientalizzante Antico. In A. Ciacci, P. Rendini and A. Zifferero (eds.), Archeologia della vite e del vino in Toscana e nel Lazio: dalle tecniche 
dell'indagine archeologica alle prospettive della biologia molecolare, 201-75. Florence: All'Insegna del Giglio.

Batino, S.

1998 Contributo alla costruzione di una ideologia funeraria etrusca arcaica: i corredi ceretani tra l'orientalizzante recente e l'età arcaica. Ostraka 5: 7-38.

Bats, M.

2006 Systèmes chronologiques et mobiliers étrusques du midi de le Gaule au premier âge du fer (v. 600-480): les rythmes de l'archéologie et de l'histoire. In S. Gori (ed.), Gli Etruschi da Genova ad Ampurias, 81-92. Pisa: Istituti editoriali e poligrafici internazionali.

Belelli Marchesini, B.

2004 Appunti sul bucchero vulcente. In A. Naso (ed.), Appunti sul bucchero, 91-147. Florence: All’Insegna del Giglio.

Bellelli, V.

2012 Particolarità d'uso della ceramica comune etrusca. Mélanges de l'École française de Rome: Antiquité 124: 277-92

Bellelli, V., and M. Botto

2002 I bacini di tipo fenicio-cipriota: considerazioni sulla diffusione di una forma ceramica nell'Italia medio-tirrenica nel periodo compreso fra il VII e il VI secolo a.C. In O. Paoletti (ed.), Etruria e Sardegna centro-settentrionale tra l'età del bronzo finale e l'arcaismo, 277-307. Pisa: Istituti editoriali e poligrafici internazionali.

Bellelli, V., and E. Benelli 
2010 Un settore 'specializzato' del lessico etrusco: una messa a punto sui nomi di vasi. Bollettino di Archeologia On Line 1: 16-26. Internet edition:

http://www.bollettinodiarcheologiaonline.beniculturali.it/bao_es.php

Berkins, J.

2003 The Orientalizing Bucchero from the Lower Building at Poggio Civitate (Murlo).

Philadelphia: University Museum, University of Pennsylvania.

Blánquez, J.

1996 Espacios sacrales en los poblados ibéricos. Los casos de El Amarejo y La

Quéjola. Revista de Estudios Ibéricos 2: 139-60.

Bonaudo, R.

2006-2007 Dalla ceramica a figure nere alla tomba del triclinio: un immaginario visuale delle rappresentazioni degli uccelli su alcuni monumenti figurati etruschi. Annali di Archeologia e Storia Antica n.s. 13-14: 157-72.

Botto, M.

2008 I primi contatti fra i Fenici e le popolazioni dell'Italia peninsulare. In S.

Celestino, N. Rafael and X.L. Armada (eds.), Contacto cultural entre el Mediterráneo y el Atlántico (siglos XII-VIII ane). La precolonización a debate, 123-48. Rome: Escuela Española de Historia y Arqueología, Roma.

2010 La ceramica fenicia dall'Etruria e dal Latium Vetus. In L. Nigro (ed.), Motya and the Phoenician Ceramic Repertoire between the Levant and the West, $9^{\text {th }}-6$ th century $B C, 151-71$. Rome: Arbor Sapientiae.

Bourdieu, $\mathrm{P}$.

1977 Outline of a Theory of Practice. Cambridge: Cambridge University Press.

Brommer, F.

1973 Vasenlisten zur griechischen Heldensage. Marburg: Elwert. 
Brun, J.-P.

2012 Le tecniche di spremitura dell'uva: origini e sviluppo dell'uso del pigiatoio e del torchio nel Mediterraneo occidentale. In A. Ciacci, P. Rendini and A. Zifferero (eds.), Archeologia della vite e del vino in Toscana e nel Lazio: dalle tecniche dell'indagine archeologica alle prospettive della biologia molecolare, 71-83. Florence: All'Insegna del Giglio.

Brousseau, L.

2010 Le monnayage des Serdaioi revisité. Revue numismatique 166: 257-85.

Camporeale, G.

1997 L'abitato etrusco dell'Accesa: il quartiere B. Rome: Giorgio Bretschneider. Cappuccini, L.

2011 Lo scarico archeologico di Monte San Paolo a Chiusi. Pisa: F. Serra editore.

Carandini, A., M.T. D’Alessio and H. Di Giuseppe (eds.)

2007 La fattoria e la villa dell'Auditorium nel Quartiere Flaminio di Roma. Rome: L'Erma di Bretschneider.

Carpenter, T.H.

1986 Dionysian Imagery in Archaic Greek Art: Its Development in Black-Figure Vase Painting. Oxford: Clarendon Press.

Carraro, F.

2007 The 'speaking objects' of Archaic Greece: writing and speech in the first complete alphabetic documents. In K. Lomas, R. Whitehouse and J. Wilkins (eds.), Literacy and the State in the Ancient Mediterranean, 65-80. London: Accordia Research Institute.

Celestino Pérez, S.

2001 Cancho Roano. Madrid: Consejo Superior de Investigaciones Cientificas. 
Cerasuolo, O.

2012 L'organizzazione del territorio di Cerveteri e dei Monti della Tolfa a confronto con l'agro tarquiniese (prima età del Ferro-età alto arcaica). Aristonothos: scritti per il Mediterraneo antico 5: 121-68.

Cerchiai, A.

2002 Il piatto della tomba 65 di Acqua Acetosa Laurentina e i pericoli del mare. Ostraka 191: 29-36.

Ciacci, A., P. Rendini and A. Zifferero (eds.)

2012 Archeologia della vite e del vino in Toscana e nel Lazio: dalle tecniche dell'indagine archeologica alle prospettive della biologia molecolare. Florence: All'Insegna del Giglio.

Ciampoltrini, G.

2016 Il porto del vino etrusco: l'insediamento arcaico di Fonteblanda. Lucca: I Segni dell'Auser.

Cifani, G.

2002 Notes on the rural landscape of Central Tyrrhenian Italy in the 6th-5th centuries and its social significance. Journal of Roman Archaeology 15: 247-60.

Colivicchi, F.

2004 L'altro vino: vino, cultura e identità nella Puglia e Basilicata anelleniche. Siris 5: 23-68.

Cristofani, M.

1971 Nuove letture di monumenti etruschi. Florence: Leo Olschki.

1987a Duo sunt liquores... In C. Cerchiai (ed.), L'alimentazione nel mondo antico, 3740. Rome: Istituto Poligrafico e Zecca dello Stato.

1987b Saggi di storia etrusca arcaica. Rome: Giorgio Bretschneider. 
Cristofani, M., P. Moscati, G. Nardi and M. Pandolfini (eds.)

1985 Il commercio etrusco arcaico. Rome: Consiglio Nazionale delle Ricerche.

d'Agostino, B.

1995 I pericoli del mare. In A. Pontrandolfo (ed.), Spunti per una grammatica dell'immaginario visuale in Modi e funzioni del racconto mitico nella ceramica greca, italiota ed etrusca dal VI al IV secolo a. C., 201-13. Salerno: Edizioni $10 / 17$

d'Agostino, B., and L. Cerchiai

1999 Il mare, la morte, l'amore: gli etruschi, i greci e l'immagine. Rome: Donzelli.

Dedet, B., and M. Py

2006 Chronologie et diffusion des importations étrusques en Languedoc Oriental. In S. Gori (ed.), Gli Etruschi da Genova ad Ampurias, 121-44. Pisa: Istituti Editoriali e Poligrafici Internazionali.

Delpino, F.

2007 Viticoltura, produzione e consumo del vino nell'Etruria protostorica. In A.

Ciacci, P. Rendini and A. Zifferero (eds.), Archeologia della vite e del vino in Etruria, 133-46. Siena: Ci.Vin.

Dietler, M.

2005 Consumption and Colonial Encounters in the Rhône Basin of France: A Study of Early Iron Age Political Economy. Lattes, France: Édition de l'Association pour le Développement de l'Archéologie en Languedoc-Roussillon.

Duranti, V.

2012 Bucchero. In M. Bonghi Jovino and G. Bagnasco Gianni (eds.), Tarquinia II. Il santuario dell'Ara della Regina. I templi arcaici, 169-215. Rome: L'Erma di Bretschneider. 
Finglass, P.J., and M. Davies (eds.)

2014 Stesichorus: The Poems. Cambridge: Cambridge University Press.

Fiorini, L.

2005 Topografia generale e storia del santuario: analisi dei contesti e delle

stratigrafie I.1. Gravisca, scavi nel santuario greco. Bari: Edipuglia.

Foxhall, L.

1998 Cargoes of the heart's desire: the character of trade in the Archaic Mediterranean world. In N. Fisher and H. van Wees (eds.), Archaic Greece: New Approaches and New Evidence, 295-309. London: Duckworth.

Gabrielli, R.

2010 Ceramica etrusco-corinzia del museo archeologico di Tarquinia. Rome: Giorgio Bretschneider.

Gailledrat, E.

2015 New perspectives on emporia in the western Mediterranean: Greeks, Etruscans and native populations at the mouth of the Lez (Hérault, Grance) during the sixthfifth centuries BC. Journal of Mediterranean Archaeology 28: 23-50.

Gómez Bellard, C., and P. Guerin

1995 Los lagares del Alt de Benimaquia (Denia) en los inicios del vino Ibérico. In M.

Celestino (ed.), Arqueología del vino: los orígenes del vino en Occidente, 243-70.

Jerez de la Frontera: Consejo Regulador de Jerez.

Govers Hopman, M.

2012 Scylla: Myth, Metaphor, Paradox. Cambridge: Cambridge University Press.

Graeber, D.

2001 Toward an Anthropological Theory of Value: The False Coin of our Own

Dreams. New York: Palgrave-Macmillan. 
2013 It is value that brings universes into being. HAU: Journal of Ethnographic Theory 3: $219-43$.

Gran-Aymerich, J., and A. Domínguez-Arranz (eds.)

2011 La Castellina a sud di Civitavecchia: origini ed eredità. Rome: L’Erma di Bretschneider.

Gras, M.

1984 Canthare, société Étrusque et mond grec. Opus 3: 325-39.

1986 La coupe et l'échange dans la Mediterranée archaïque. In H. Altenmüller (ed.), Hommages à François Daumas, 351-59. Montpellier: Institut d'Egyptologie, Université Paul Valery.

Hanson, V.D.

1992 Practical aspects of grape-growing and the ideology of Greek viticulture. In B. Wells (ed.), Agriculture in Ancient Greece, 161-66. Uppsala: Paul Åströms Förlag.

Iozzo, M.

2009 Un nuovo dinos da Chiusi con le nozze di Peleus e Thetis. In E. Moormann and V.V. Stissi (eds.), Shapes and Images: Studies on Attic Black Figure and Related Topics in Honour of Herman A.G. Brijder, 63-85. Leuven: Peeters.

Isager, S., and J.E. Skydsgaard

1995 Ancient Greek Agriculture: An Introduction. London and New York: Routledge. Isler-Kerenyi, $\mathrm{C}$.

2007 Dionysos in Archaic Greece. Leiden: Brill.

Izzet, V.

2007 The Archaeology of Etruscan Society. Cambridge: Cambridge University Press. Johnston, A. 
1987 Amasis and the vase trade. In M. True (ed.), Papers on the Amasis Painter and his World, 125-40. Los Angeles: J. Paul Getty Museum.

Keane, W.

1994 The value of words and the meanings of things in eastern Indonesian exchange. Man (n.s.) 29: 605-29.

Kistler, E., and M. Mohr

2015 Monte Iato: two late Archaic feasting places between the local and the global. In

E. Kistler, B. Öhlinger, M. Mohr and M. Hoernes (eds,), Sanctuaries and the Power of Consumption: Networking and the Formation of Elites in the Archaic Western Mediterranean World: 385-415. Wiesbaden: Harrassowitz Verlag.

Kluiver, J.

1993 The potter-painters of 'Tyrrhenian' neck-amphorae: a close look at the shape. Babesch 68: 73-109.

2003 The Tyrrhenian Group of Black-Figure Vases. Ghent: Academia Press.

Krotscheck, U.

2015 Pointe Lequin 1A: wine cups and economic networks in the western Mediterranean. Ancient West and East 14: 169-89.

Lambek, M.

2013 The value of (performative) acts. HAU: Journal of Ethnographic Theory 3: 14160.

Lebeaupin, D., P. Séjalon, I. Fauduet and I. Odenhardt-Donvez

2008 Lattara et l'Étrurie: nouvelles données sur l'installation d'un comptoir vers 500 av. J.-C. Gallia 65: 45-64.

Lentjes, D., and G. Saltini Semerari 
2016 Big debates over small fruits. Oil and wine production in protohistoric southern Italy. Babesch 91: 1-16.

Lissarrague, F.

1987 Un flot d'images: un esthétique du banquet grec. Paris: Adam Biro.

Locatelli, D.

2001 Bucchero. In M. Bonghi Jovino and G. Bagnasco Gianni (eds.), Tarquinia: scavi sistematici nell'abitato, campagne 1982-1988. I materiali vol. 2, 187-332. Rome: L'Erma di Bretschneider.

2004 Tarquinia. In A. Naso (ed.), Appunti sul bucchero, 49-89. Florence: All'Insegna del Giglio.

Long, L., and J.-C. Surrisseau

2002 Épave de La Love (Cap d'Antibes). In L. Long, P. Pomey and J.-C. Surrisseau (eds.), Les Étrusques en mer: épaves d'Antibes à Marseilles, 25-31. Aix-enProvence: Edisud.

Long, L., L.-F. Gantès and M. Rival

2006 L'épave grand Ribaud F in Gori/Genova convegno. In S. Gori (ed.), Gli Etruschi da Genova ad Ampurias, 455-95. Pisa: Istituti Editoriali e Poligrafici Internazionali.

Maras, D.F.

2009 Il dono votivo, gli dei e il sacro nelle iscrizioni etrusche di culto. Rome: F. Serra Editore.

2013 Area Sud: ricerche in corso sulla documentazione epigrafica (contesti, supporti, formulary, teonimi). In M.P. Baglione and M.D. Gentili (eds.), Riflessioni su Pyrgi: scavi e ricerche nelle aree del santuario, 195-206. Rome: L'Erma di Bretschneider. 
Marchetti, M.H.

2004 La produzione del bucchero a Veio: alcune considerazioni. In A. Naso (ed.), Appunti sul bucchero, 17-27. Florence: All'Insegna del Giglio.

Martelli, M.

1987a Del Pittore di Amsterdam e di un episodio del nostos odissaico. Prospettiva 50: 4-14.

1987b La ceramica etrusco-corinzia. In M. Martelli (ed.), La ceramica degli etruschi: la pittura vascolare, 269-96. Novara, Italy: Istituto Geografico De Agostini.

McGovern, P.E., B.P. Luley, N. Rovira, A. Mirzoian, M.P. Callahan, K.E. Smith, G.R. Hall,

T. Davidson and J.M. Henklin

2013 Beginning of viniculture in France. Proceedings of the National Academy of Sciences of the United States of America 110 (25): 10147-52.

Menichetti, M.

1994 Archeologia del potere: re, immagini e miti a Roma e in Etruria in etMirzoian.

Milan: Longanesi.

Micozzi, M.

2005 'White-on-red': miti greci nell'Orientalizzante etrusco. In B. Adembri (ed.), Aeimnestos: miscellanea di studi per Mauro Cristofani, vol. 1, 256-66. Florence: Centro Di.

Miyazaki, H.

2010 Gifts and exchange. In M.C. Beaudry and D. Hicks (eds.), The Oxford Handbook of Material Culture Studies, 246-64. Oxford: Oxford University Press.

Moore, M.B.

2010 Hephaistos goes home: an Attic Black-Figure column-krater in the Metropolitan Museum. Metropolitan Museum Journal 45: 21-54. 
2011 Kleitias, Dionysos and Cheiron. Babesch 86: 1-13.

Morandini, F.

2011 Le fattorie arcaiche di Pian d'Alma (Scarlino - GR) e Marsiliana d'Albegna (Manciano - GR): modello ‘urbano' esportato in campagna o modello ‘extraurbano' radicato nella tradizione? In A. Ellero, F. Luciano and A. Zaccaria Ruggiu (eds.), La città: realtà e valori simbolici, 79-100. Padova: S.A.R.G.O.N. editrice.

Nardi, G., and M. Pandolfini

1985 La diffusione delle anfore etrusche nell'Etruria settentrionale. In M. Cristofani, P. Moscati, G. Nardi and M. Pandolfini (eds.), Il commercio etrusco arcaico, 41-63. Rome: Consiglio Nazionale delle Ricerche.

Osborne, R.

2007 What travelled with Greek pottery? Mediterranean Historical Review 22: 85-95. Paleothodoros, D.

2007 Dionysiac imagery in Archaic Etruria. Etruscan Studies 10: 187-201.

2009 Archaeological context and iconographic analysis: case-studies from Greece and Etruria. In V. Nrskov, L. Hannestad, C. Isler-Kerenyi and S. Lewis (eds.), The World of Greek Vases, 45-62. Rome: Edizioni Quasar.

2011 A complex approach to Etruscan Black-Figure vase-painting. Mediterranea 8: 33-82.

Papadopoulos, J.

2012 Money, art, and the construction of value in the ancient Mediterranean. In J. Papadopoulos and G. Urton (eds.), The Construction of Value in the Ancient World, 261-87. Los Angeles: UCLA Cotsen Institute of Archaeology Press. Papadopoulos, J., and G. Urton (eds.) 
2012 The Construction of Value in the Ancient World. Los Angeles: UCLA Cotsen Institute of Archaeology Press.

Paribeni, E.

2009 Pian d'Alma (Scarlino): una fattoria tardo arcaica. In S. Bruni (ed.), Etruria e Italia preromana: studi in onore di Giovannangelo Camporeale, 666-72. Rome:

F. Serra editore.

Pavlou, M.

2012 Sirens at the symposium (Louvre E667). Mnemosyne 65: 401-12.

Perkins, $\mathrm{P}$.

1999 Etruscan Settlement, Society and Material Culture in Central Coastal Etruria.

Oxford: Archaeopress.

2012 Production and commercialization of Etruscan wine in the Albegna Valley. In A.

Ciacci, P. Rendini and A. Zifferero (eds.), Archeologia della vite e del vino in

Toscana e nel Lazio: dalle tecniche dell'indagine archeologica alle prospettive

della biologia molecolare, 413-26. Florence: All’Insegna del Giglio.

Perkins, P., and S. Walker

1990 Survey of an Etruscan city at Doganella in the Albegna Valley. Papers of the British School at Rome 58: 1-103.

Rasmussen, T.

1979 Bucchero Pottery from Southern Etruria. Cambridge: Cambridge University Press.

Rathje, A.

1983 A banquet service from the Latin city of Ficana. Analecta Romana 12: 7-29. Rendeli, M. 
1993 Città aperte: ambiente e paesaggio rurale organizzato nell'Etruria meridionale costiera durante l'età orientalizzante e arcaica. Rome: Gruppo Editoriale Internazionale.

Ridgway, D.

1997 Nestor's cup and the Etruscans. Oxford Journal of Archaeology 16: 325-44. Riva, C.

2010a Trading settlements and the materiality of wine consumption in the north Tyrrhenian Sea region. In P. van Dommelen and A.B. Knapp (eds.), Material Connections in the Ancient Mediterranean. Mobility, Materiality, Identity, 21032. London and New York: Routledge.

2010b The Urbanisation of Etruria: Funerary Practices and Social Change, 700-600 $B C$. Cambridge: Cambridge University Press.

Rizzo, M.A.

1990 Le anfore da trasporto e il commercio etrusco arcaico. Rome: De Luca. Romanelli, P.

1948 Tarquinia: scavi e ricerche nella città. Notizie degli Scavi 73: 193-270. Santocchini Gerg, S.

2014 Incontri tirrenici: le relazioni fra Etruschi, Sardi e Fenici in Sardegna (630-480 a.C.). Bologna: Bononia University Press.

Schauenburg, K.

1971 Herakles bei Pholos: zu zwei frührotfigurigen Schalen. Mitteilungen des Deutschen Archäologischen Instituts, Athenische Abteilung 86: 43-54. Serra Ridgway, F.R.

2010 Pithoi stampigliati ceretani: una classe originale di ceramica etrusca. Rome: Lomasse originale di cer 
Szilagyi, J.G.

1998 Ceramica etrusco-corinzia figurata. Florence: Leo S. Olschki Editore.

Thomas, N.

1991 Entangled Objects: Exchange, Material Culture and Colonialism in the Pacific.

Cambridge, Massachusetts: Harvard University Press.

Torelli, M.

2004 Un dono per gli dei: kantharoi e gigantomachie. A proposito di un kantharos a figure nere da Gravisca. In K. Lomas (ed.), Greek Identity in the Western Mediterranean: Papers in Honour of Brian Shefton, 211-28. Leiden: Brill.

2007 Le strategie di Kleitias: composizione e programma figurativo del vaso François. Milan: Electa.

Valenza Mele, $\mathrm{N}$.

1986 Il ruolo dei centauri e di Eracle: polis, banchetto e simposio. In P. Lévêque and M. Mactoux (eds.), Les grandes figures religieuses: fonctionnement pratique et symbolique dans l'antiquité, 333-70. Paris: Belles Lettres.

Van Der Mersch, C.

1998 Vigne, vin et économie dans l'Italie du Sud grecque a l'époque archaïque. Ostraka $5,155-85$

van Dommelen, P., C. Gómez Bellard and C. Tronchetti

2012 Insediamento rurale e produzione agraria nella Sardegna punica: la fattoria di Truncu 'e Molas (Terralba, OR). In C. Del Vais (ed.), EPI OINOPA PONTON: studi sul Mediterraneo antico in ricordo di Giovanni Tore, 501-16. Oristano: S'Alvure.

Verbanck-Piérard, A. 
1982 La rencontre d'Héraklès et de Pholos: variantes iconographique du peintre d'Antiménès. In L. Hadermann-Misguich and G. Raepsaet (eds.), Rayonnement grec: hommages à Charles Delvoye, 143-54. Brussels: Éditions de l'Université de Bruxelles.

Wallace, R.E.

2008 Muluvanice inscriptions at Poggio Civitate (Murlo). American Journal of Archaeology 112: 449-558.

Werner, I.

2005 Dionysos in Etruria: The Ivy Leaf Group. Stockholm: Åström Editions. Zifferero, A.

2010 Nuovi dati dall'agro vulcente: il Progetto Marsiliana d'Albegna (2002-2009). Archeologia uomo territorio 29: 1-29.

2017 Le attività artigianali nel territorio vulcente: la valle dell'Albegna e Marsiliana. In M.C. Biella (ed.), Gli artigiani e la città: officine e aree produttive tra VIII e III sec. a. C. nell'Italia centrale tirrenica. Scienze dell'Antichità 23: 305-23. Rome: Quasar.

Zifferero, A., A. Pecci, A. Pepi, C. Sanchirico and E. Santoro

2011 Marsiliana d'Albegna: nuovi dati dall'area suburbana. In G. Facchin and M. Milletti (eds.), Materiali per Populonia 10: 289-320. Edizioni ETS: Pisa.

\section{Captions}

Figure $1 \quad$ Map of the central Mediterranean with sites mentioned in text. 1: Massalia; 2: Sant'Imbenia; 3: Sulky; 4: Nora; 5: San Rocchino; 6: Chiusi; 7: Vetulonia; 8: Podere Tartuchino; 9: Marsiliana; 10: Doganella; 11: Vulci; 12: Regisvilla; 
13: Tarquinia; 14: Gravisca; 15: Tolfa Hills; 16: Caere; 17: Veii; 18: Laos; 19: Naxos.

Figure 2 The first Pania pyxis vessel with detail of the amphora-carrying ship (licensed by the Ministero dei Beni e delle Attività Culturali e del Turismo—Polo museale della Toscana—Firenze. Unauthorized reproduction of these images by any means, in whole or part, is strictly prohibited).

Figure 3a-c The Gobbi Krater, Caere, showing the main frieze depicting (a) Herakles and (b) and Pholos (licensed by the Ministero per i Beni e le attività culturaliImmagine della Soprintendenza per i Beni Archeologici dell'Etruria Meridionale, Inv. 19539); drawing (c) of the decorative friezes (adapted from Martelli 1987b)

Figure 4 White-on-Red amphora, Caere (Courtesy of the Civico Museo Archeologico di Milano, Collezione Lerici).

Figure 5 White-On-Red pithos with lid, Caere (Digital image courtesy of the Getty's Open Content Program).

Figure 6 Black-Figure dinos, Chiusi, with detail of Dionysos walking in the procession (licensed by the Ministero dei Beni e delle Attività Culturali e del TurismoPolo museale della Toscana-Firenze. Unauthorized reproduction of these images by any means, in whole or part, is strictly prohibited).

Figure 7 François Vase, Chiusi, with detail of Dionysos facing the viewer (licensed by the Ministero dei Beni e delle Attività Culturali e del Turismo-Polo museale della Toscana-Firenze. Unauthorized reproduction of these images by any means, in whole or part, is strictly prohibited).

Figure 8a-b Belly amphora (licensed by the Ministero dei Beni e delle Attività Culturali e del Turismo—Polo museale della Toscana_Firenze. Unauthorized 
reproduction of these images by any means, in whole or part, is strictly prohibited).

Figure 6 White-On-Red pithos with lid, Caere (Digital image courtesy of the Getty's Open Content Program).

Figure 7 Black-Figure dinos, Chiusi (Firenze, Museo Archeologico Nazionale).

Figure 8 François Vase, Chiusi (Firenze, Museo Archeologico Nazionale).

Figure 9 Belly amphora (inv. 3812, Firenze, Museo Archeologico Nazionale). 